Editorial

\title{
Mass Atrocity Prevention: Forever Elusive or Potentially Achievable?
}

\author{
Karen E. Smith \\ Department of International Relations, London School of Economics and Political Science, London, WC2A 2AE, UK; \\ E-Mail: k.e.smith@lse.ac.uk
}

Submitted: 17 September 2015 | Published: 27 October 2015

\begin{abstract}
This editorial introduces the special issue, and considers what the articles in it tell us about the prospects of mass atrocity prevention.
\end{abstract}

\section{Keywords}

mass atrocities; mass atrocity prevention; responsibility to protect

Issue

This editorial is part of the special issue "Mass Atrocity Prevention", edited by Professor Karen E. Smith (London School of Economics and Political Science, UK).

(C) 2015 by the author; licensee Cogitatio (Lisbon, Portugal). This article is licensed under a Creative Commons Attribution 4.0 International License (CC BY).

\section{Introduction}

Can mass atrocities be prevented, and if so, how? Mass atrocity prevention has become a "growth area" in the academic literature, and in the policy world, as seen in an increasing number of academic articles and books on the topic (see, for example: Bellamy, 2011; Cushman, 2003; Evans, 2008; Gosldstone et al., 2010; Hamburg, 2010; Stamnes, 2008; Zartman, 2010), and increasing attention given to mass atrocity prevention by UN officials, by governments, and by NGOs. Various task forces-most prominently the US Task Force on Genocide Prevention-have made recommendations to governments (Genocide Prevention Task Force, 2008; Task Force on the EU Prevention of Mass Atrocities, 2013; Montreal Institute for Genocide and Human Rights Studies, 2009), the UN Office of the Special Adviser on the Prevention of Genocide has made proposals to strengthen mass atrocity prevention (UN, 2014), and NGOs such as The Stanley Foundation and the Global Centre for the Responsibility to Protect have large and well-respected prevention programmes. The US Holocaust Memorial Museum recently launched the "Early Warning Project", to provide analysis of the risks of mass atrocities occurring around the world.

Reflecting this context, the call for papers for this special issue generated a large response, such that the accepted articles will actually fill two volumes. The special issue contains articles that analyse and contribute to the state of knowledge regarding factors that could lead to the perpetration of mass atrocities, and that critically assess responses to potential or ongoing situations of mass atrocities. The articles should prompt further debate in the academic literature, and among policy entrepreneurs and policy-makers.

\section{Special Issue: Part 1}

The first part of the special issue contains papers that consider and assess the factors that lead to mass atrocities, which could thus form part of strategy to prevent atrocities. A key overall lesson that emerges in this part is that knowledge of the context and conditions in particular cases of possible mass atrocity situations is crucial: policy toolkits and frameworks can provide a starting point in any mass atrocity prevention strategy, but without knowledge and intelligence of the local and regional dynamics, prevention strategies are unlikely to be effective.

In "Triggers of Mass Atrocities", Scott Straus analyses the utility of the concept of "triggers" in understanding and preventing mass atrocities. He finds that in some cases there are indeed "turning points" after which violence sharply escalates. But he still urges cau- 
tion because the same sort of trigger may lead to different outcomes, and there are factors other than the trigger itself that matter if mass atrocities are perpetrated. Knowledge of specific cases could still, however, enable observers to try to predict whether certain triggers could lead to an escalation of violence.

Cecilia Jacob's "Evaluating the United Nation's Agenda for Atrocity Prevention" critiques the UN's framework for analysing atrocity crimes (UN, 2014). Using Pakistan as a case study, she shows that the framework would be more effective if it took into account the relational dynamics of atrocity crimes, and the links between the micro and macro dynamics of political violence in specific situations.

In "Understanding Mass Atrocity Prevention during Periods of Democratic Transition", Stephen McLoughlin compares the transitions in the early 1990s in Burundi and Guyana, and considers why processes of democratisation broke down into mass atrocities in the first case but not in the second. The explanation centres on the regional context and history of past atrocities, the quality of domestic political competition, and the state of the armed forces in each country. The analysis yields insights for prevention, pointing to the principal actors responsible for avoiding risk escalation, and the factors that can inhibit violence during times of heightened tension.

Collette Mazzuccelli and Dylan Hendon's “Unearthing Truth: Forensic Anthropology, Translocal Memory, and 'Provention' in Guatemala" also focuses on the "local", in particular how families can contribute to mass atrocity prevention by pressing for transitional justice. They argue for "drilling down" to the structural roots of conflict so as to better understand how the risks of atrocities can be overcome.

In "Stopping Mass Atrocities: Targeting the Dictator", Maartje Weerdesteijn argues that atrocities are often perpetrated in authoritarian regimes where crimes are legitimised through ideology. She compares the extent to which Pol Pot and Slobodan Milosevic were truly motivated by ideology or were using it instrumentally. She argues that leaders that are ideological are less responsive to international pressure and action than leaders that are non-ideological.

Ideology is also the focus of "Preventing Mass Atrocities: Ideological Strategies and Interventions", by Jonathan Leader Maynard. He argues that as ideology plays a role in the perpetration of mass atrocities, ideologies should also be studied from the perspective of mass atrocity prevention. Ideological strategies and interventions - such as peace broadcasting, peace education, or jamming anti-civilian media messages - should be used as part of broader prevention strategies.

A more critical view of the potential of prevention is provided in "The Viability of the 'Responsibility to Prevent'". Aidan Hehir casts doubt on the efficacy of prevention because the vast array of factors that might lead to mass atrocities makes early warning difficult, there is no clear causal link between various danger signs and the actual occurrence of mass atrocities, and the response of the "international community" to potential mass atrocities depends on the political will of states, which is also variable. Prevention is not impossible, but depends entirely on the "whims of particular states" and their "often nefarious political interests".

The final article in the first part of the special issue is a commentary by Bridget Moix, which examines the progress in protecting civilians from mass violence since the Responsibility to Protect appeared in the 2005 World Summit Outcome Document. She argues that in future there should be a greater focus on "upstream" prevention (that is, prevention well before violence is under way), and on strengthening local capacities to minimise the risks of atrocities and mass violence.

\section{Special Issue: Part 2}

The second part of the special issue critically assesses the response of a variety of actors to mass atrocities. The articles tend to consider the failures and limits of responses by states, international organisations, and regional organisations to situations of mass atrocities, though some authors point to progress made in terms of accepting the responsibility to protect populations from mass atrocities. Many, but not all, of the articles in this part focus on the cases of Libya and Syria, two of the most recent and high-profile cases in which large numbers of people have been killed amid much criticism of outsiders' response.

The response of a variety of states to mass atrocities by Indonesia in East Timor in the late 1970s is the focus of Clinton Fernandes' article, "Accomplice to Mass Atrocities". He argues that Australia, the US, New Zealand and Canada did not "look away" but rather that they were aware of the humanitarian crisis and nonetheless provided military and diplomatic aid to Indonesia, which was largely responsible for the crisis. Intelligence and early warning, in other words, may not lead states to try to stop atrocities.

States have since declared that they have a responsibility to protect populations from atrocity crimes. One key question is what would drive states to fulfil this responsibility? In "Genocide Prevention and Western National Security: The Limitations of Making R2P All About Us", Maureen S. Hiebert analyses two wellknown policy reports (Genocide Prevention Task Force 2008 and Montreal Institute for Genocide and Human Rights Centres 2009) that recommend atrocity prevention. She argues that both reports make the case for prevention on national security grounds, but the problem is that it is difficult to prove that national security interests are in fact implicated in particular cases of mass atrocities. Instead, western states might be motivated to prevent and respond to atrocities if it can be 
shown that doing so is linked to safeguarding their reputations as responsible members of the international community.

Matthew Levinger's article, "A Core National Security Interest: Framing Atrocities Prevention", illustrates how problematic the link is between mass atrocity prevention and national security interests. He analyses US President Barack Obama's communication strategies regarding threats of mass atrocities in Libya, Syria and Iraq, and shows that hardly ever did Obama's speeches make a link to threats to US national security.

The next two articles examine the policies and actions of two regional organisations, the European Union and NATO. "Is a European Practice of Mass Atrocity Prevention Emerging? The European Union, Responsibility to Protect and the 2011 Libya Crisis?", by Chiara De Franco and Annemarie Peen Rodt, analyses the European Union's practices during and after the 2011 Libya crisis. They argue that the crisis prompted the EU to incorporate-to a greater extent than ever before-its own interpretation of the responsibility to protect into its security culture and policy-making structures, largely by integrating it into its "comprehensive approach" to security and development.

NATO's actions in the 2011 Libya crisis are excoriated by Jeffrey Bachman in "R2P's 'Ulterior Motive Exemption' and the Failure to Protect in Libya". Bachman's critique of the NATO intervention centres on its ulterior motive for intervention-the overthrow of Qaddafi-which meant that it not only exceeded the UN Security Council's R2P mandate, but supported rebels who were committing human rights abuses and failed to protect civilians after Qaddafi was executed. Bachman's article again illustrates the dangers and dilemmas posed by linking national interests (in regime change) with the will to intervene to protect populations from mass atrocities.

The criticism of international responses to mass atrocities continues in the commentary, "Is R2P a FullyFledged International Norm?", by Jason Ralph and James Souter. They argue that outside actors have done more than just fail to respond to the atrocities inside Syria: they have failed to protect the refugees that have fled the atrocities, and have thus failed to fulfil their responsibilities to protect populations, just as they failed to help rebuild Libya after the 2011 crisis. Their argument is even more forceful considering the unprecedented refugee 'crisis' now facing Europe and the disturbing disarray it has provoked among governments.

Policy-makers clearly struggle with unpalatable dilemmas when mass atrocities are being perpetrated, as the range of possible and effective response narrows with escalations of violence. In "Perpetrators, Presidents, and Profiteers: Teaching Genocide Prevention and Response through Classroom Simulation", Waitman Wade Beorn shows how such dilemmas can be investigated in the classroom, through a simulation called GENPREVEX. Simulations have the potential to teach students about the complexities faced by decision-makers, and to be more aware of the world around them.

\section{Conclusion}

So is mass atrocity prevention an elusive or a realisable goal? Several of the articles in this special issue illustrate the challenges and limits of prevention policies and strategies, and cast particular doubt on the willingness and ability of various members of the "international community" to respond to possible and ongoing mass atrocities in a way that leads to their containment or termination. But this special issue also highlights several factors that, if incorporated into mass atrocity prevention strategies, could ultimately lead to fewer atrocities occurring worldwide. These could lead to more effective and legitimate "upstream" strategies that are based on expert knowledge of particular contexts and in conjunction with local actors.

\section{Conflicts of interest}

The author declares no conflicts of interest.

\section{References}

Bellamy, A. J. (2011). Mass atrocities and armed conflict: Links, distinctions, and implications for the responsibility to prevent (Policy Analysis Brief). Muscatine, IA: The Stanley Foundation.

Cushman, T. (2003). Is genocide preventable? Some theoretical considerations. Journal of Genocide Research, 5(4), 523-542.

Evans, G. (2008). The responsibility to protect: Ending mass atrocity crimes once and for all. Washington, DC: Brookings Institution.

Genocide Prevention Task Force. (2008). Preventing genocide: A blueprint for U.S. Policymakers. USA: US Holocaust Memorial Museum, American Academy of Diplomacy, US Institute for Peace.

Goldstone, J. A., Bates, R. H., Epstein, D. L., Gurr, T. R., Lustik, M. B., Marshall, M. G., Ulfedler, J., \& Woodward, M. (2010). A global model for forecasting political instability. American Journal of Political Science, 54(1), 190-208.

Hamburg, D. A. (2010). Preventing genocide: Practical steps toward early detection and effective action. Boulder, CO: Paradigm Publishers.

Montreal Institute for Genocide and Human Rights Studies. (2009). Mobilizing the will to intervene: Leadership and action to prevent mass atrocities. Montreal: Montreal Institute for Genocide and Human Rights Studies.

Stamnes, E. (2008). Operationalising the preventive aspects of the responsibility to protect (NUPI Report 
Responsibility to Protect, no. 1). Oslo: NUPI.

Task Force on the EU Prevention of Mass Atrocities.

(2013). The EU and the prevention of mass atroci-

ties: An assessment of strengths and weaknesses.

Budapest: Budapest Centre for the International

Prevention of Genocide and Mass Atrocities.
United Nations. (2014). Framework of Analysis for Atrocity Crimes: A Tool for Prevention. New York: UN.

Zartman, I. W. (2010). Preventing identity conflicts leading to genocide and mass killings. New York: International Peace Institute.

\section{About the Author}

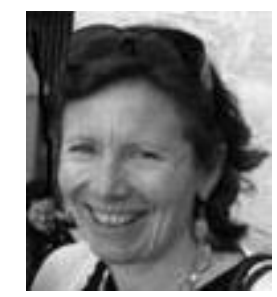

\section{Dr. Karen E. Smith}

Karen E. Smith is Professor of International Relations at the London School of Economics and Political Science. She has written extensively on European Union foreign policy, EU human rights policy, EUUN relations and European policies regarding genocide and the responsibility to protect. In 2012-13, she co-chaired the Task Force on EU Prevention of Mass Atrocities, whose report was published in March 2013. 